Preliminary communication UDC 159.923.2+ 17.026.1

$+616.89-008.442 .6(045)$

doi: $10.21464 / \mathrm{sp} 35101$

Received: 16 April 2020

\author{
Bernard Špoljarić \\ Avenija Dubrava 240, HR-10040 Zagreb
}

bernard.spoljar@gmail.com

\title{
Ego Complexities
}

\begin{abstract}
The research on the complexities of ego has its starting point in the self, understood as a complex concept, superior to the diagnostic constructs that tend to perform the medical-qualitative evaluation of each self. Besides explaining the notion, the aim is to emphasise the clear distinction between egoism and narcissism, with narcissism being merely one of the possible modes and explanations of self, i.e. general and universal domain of subjectivity. Complexities primarily indicate the unsolved intricacy of ego, together with the associated concepts of subjectivity and individuality. The outline of the general model of the ego, its constitution and operability, provides a possible common basis for a therapeutic, philosophical and moral understanding of aporias related to the psychopathological states present in the seemingly emancipated complete individual.
\end{abstract}

\section{Keywords}

cognition, complexity, ego, egoism, ipseity, narcissism, prover, psyche, subjectivity, thinker

\section{Introduction}

According to the classic definition, word complex derives from Latin word complexus, meaning encompassing. There are several aspects of this notion. As an adjective complex describes that which is "composed of interconnected parts, formed by a combination of simple things or elements (...) 'complicated, complex, intricate""; 1 while as a noun, complex is "a whole comprised of interconnected parts". ${ }^{2}$ Therefore, regarding this first, general meaning of the notion of complexity, it is important to state that complex or complexity is a set, "having many parts related to each other in ways that may be difficult to understand". ${ }^{3}$ An important feature of a unit understood to be a complex is that it is composed of many parts connected, while these parts remain specifically variant in their being, which makes a relation of theirs to each other difficult to understand. All of these aspects emphasise perplexity as an outline of complexity.

Another important understanding of the notion of complex is closely related to the psychiatric, psychological and psychopathological discourses, because of the philosophically understood notion of psyche. These aspects of complexity hold significant meaning when complexities of ego are in question.

1

"complex" (adj.), Online Etymology Dictionary. Available at: https://www.etymonline. com/word/complex (accessed on 16 April 2020).

2

Ibid.
3

"complex", Cambridge Dictionary. Available at: https://dictionary.cambridge.org/dictionary/english/complex (accessed on 16 April 2020). 
Even though the notion of ego might seem to hold much less intricacy than the notion of complexity, at least regarding its meaning and translation, as a simple "I", or "ipseity"; the inquiry of the ego will reveal that ego itself is intricate and complex. In this respect, complexities of ego signify both psychopathological states of ego as an individual psyche and ego as universally complex formation.

The focus of this article is on the ego complexities, a concept differentiated from the psychological notion of the complex. In that respect, the ego is observed as a composite compiler of cognitive content, based on the complementary configuration of historical and present bio-social properties through which it attains its self-consciousness. The starting point of the paper is the demonstration of the precedence and universality of ego to possible character explications perceived as personalities, with focus on narcissism. Besides elaboration on the clear and distinct difference between egoism and narcissism, as two observably different types of self-centeredness, the deliberation on ego complexities considers narcissistic traits as a specific impediment to sound reasoning and realisation of the individual self. The desired outcome is to provide common ground for an understanding of ego, its features and operations, which would help clarify confusions as pathological states of the psyche that are recognisable as problems in the cognitive process, both on the individual level of introspection, and the level of societal perception; as well as the treatment of different explications of variable egos.

\section{Egoism Is Not Narcissism}

A common misconception that frequently appears as a conceptual dissonance is the one when the ego (or egoism and egocentrism) is equalised with the description of narcissism. It is important to accentuate and elaborate the fine reason why separate notions exist, indicating that one is not reducible to another. The term narcissism has its deepest roots in Greek mythology, in the story of Narcissus, the hunter of irresistible beauty. The most notable version of the myth in this genealogy of narcissism is the story of Echo and Narcissus from Ovid's Metamorphoses. Given the tragic character of the myth, the term narcissism is often used to designate excessive self-love and self-admiration. ${ }^{4}$ In understanding narcissism, excessiveness is emphasised, which is enough to distinguish between narcissistic and non-narcissistic character, without the need of introducing notions of "positive" and "negative" narcissism.

"While self-centredness does not express fully what narcissism is, if it is taken as a provisional definition it makes some sort of sense to talk about 'healthy selfishness'. On the other hand, it is meaningless to talk about healthy self-centredness. If, by positive narcissism, confidence in oneself is meant, then fair enough - but that is not narcissism."

These remarks are to a certain extent related to the designation of narcissism already presented by Sigmund Freud in his 1914 essay On Narcissism, which is also the study of narcissism separated from the mythological origins of the concept, and rather related to the specific libidinal distribution. ${ }^{6}$ In Freudian sense, narcissism, as "libidinal complement to the egoism of the instinct of self preservation", ${ }^{7}$ is a state recognizable when libido withdraws from the objects of the external world. Once the libido finds its object in the ego, it is appropriate to speak of narcissism. ${ }^{8}$ The self-centredness within this discourse has a meaning of a certain auto-eroticism, required for the development of ego, ${ }^{9}$ which is not equal to the state of narcissism and therefore it requires a 
new element. Moreover, such distinction between sexual instincts and ego-instincts conditions the phenomenality of narcissism, as libido problem. Freud demonstrates the occurrence of narcissism within fields of organic diseases, hypochondria and the erotic life of the sexes. ${ }^{10}$ With organic diseases, when libido retreats from the interaction with the objects of the external world, it is left with the cathexis in ego; this giving the clear example of how wantage of difference between ego-instincts ${ }^{11}$ and libido ${ }^{12}$ results in introversion, which manifests as narcissism. This concept that begins with the object-choice emphasises the desire for self-consumption as a particular narcissistic trait.

There is yet another distinction that concerns narcissism, and it is the one that distinguishes narcissistic character (or behaviour) from pathological narcissism and the long-term narcissistic personality disorder.

"What distinguishes narcissistic behavior from pathological narcissism are frequency, intensity, and duration. While some people may exhibit narcissistic traits occasionally and mildly, a pathological narcissist will routinely use destructive narcissistic tactics in order to gain false superiority and exploit relationships." 13

This destructive aspect of narcissistic behaviour is not only present on an inter-personal level, but, as will be argued in the following subsections, also is present on the level of internal psychic processes of an individual, as well as on inter-social level. When the narcissistic tendencies are present on any of the mentioned levels, "the hapless narcissistic subject becomes divided into dissociated sub-selves or alter egos that conflict with one another, defy integration, and forfeit their sense of spontaneous agency of initiative". ${ }^{14}$ The

4

"How the narcissus myth came to represent self-love or self-admiration is unclear, but in art and literature during the medieval and early Renaissance eras the theme was used to illustrate the dangerous sinfulness and deadly punishment attached to excessive self-preoccupation and self-adulation." - Elsa F. Ronningstam, Identifying and Understanding the Narcissistic Personality, Oxford University Press, New York (NY) 2005, pp. 3-4.

5

Neville Symington, Narcissism: A New Theory, Karnac Books, London 1993, p. 8.

6

"The term narcissism is derived from clinical description and was chosen by Paul Näcke in 1899 to denote the attitude of a person who treats his own body in the same way in which the body of a sexual object is ordinarily treated - who looks at it, that is to say, strokes it and fondles it till he obtains complete satisfaction through these activities." - Sigmund Freud, "On Narcissism: an Introduction (1914)", in: Sigmund Freud, The Standard Edition of the Complete Psychological Works of Sigmund Freud. Volume XIV (1914-1916) On the History of the Psycho-Analytic Movement, Papers on Metapsychology and Other Works, The Hogarth Press, Institute of Psycho-Analysis, London 1957, pp. 67-102, p. 73.
7

Ibid., pp. 73-74.

8

There are different states in which libido diversifies from the external world, but if it is not directed to ego, these states are not qualified as narcissism.

Cf. S. Freud, "On Narcissism: an Introduction (1914)", p. 77.

10

Cf. ibid., p. 82 .

11

"Healthy" auto-erotic-self-centredness.

12

Instinct for interaction with external objects. 13

Preston Ni, "Difference Between a Narcissist vs. Narcissistic Behavior", Psychology Today (11 August 2019). Available at: https://www. psychologytoday.com/us/blog/communication-success/201908/difference-between-narcissist-vs-narcissistic-behavior (accessed on 28 August 2020).

14

James S. Grotstein, "Foreword", in: N. Symington, Narcissism, pp. ix-xvi, p. x. 
definition of narcissistic personality disorder (NPD) rests upon following diagnostic features:

"The essential feature of Narcissistic Personality Disorder is a pervasive pattern of grandiosity, need for admiration, and lack of empathy that begins by early adulthood and is present in a variety of contexts. Individuals with this disorder have a grandiose sense of self-importance (Criterion 1). They routinely overestimate their abilities and inflate their accomplishments, often appearing boastful and pretentious." 15

These diagnostic features describe only a small part of the characteristics of the NPD, being the ones that represent the ground characteristics. From the diagnostic description of NPD, it is clear that there is a certain set of features ascribed to a specific concept of an ego, or self. Furthermore, this clarifies that narcissism is a description of some particular personality, recognised as such according to the clearly and distinctively established attributes and therefore cannot validly represent the same things to which this set of attributes is imprinted on. Narcissism can also be phrased as an excessive self-fascination, or as unrestrained selfishness in the interaction with the surrounding world, if selfishness is the attribute that is being put in the forefront. In this relation, ego is the notion with a much broader meaning and grasp. Ego is a general, universal self or general, i.e. universal subject, which in relation to narcissism or any other set of attributes stands as capacity, substratum or substance; which is formable and explicable in a variety of ways. From this point, egoism represents the universal state of human being, or, if understood as a position, then it can be designated as egocentrism - as a cognitive bias.

"As a cognitive bias, egocentrism refers to the natural restriction on our perception caused by the simple fact that we can only see the world from our perspective. It takes special effort to see the world from any other perspective other than through our own eyes." 16

Attaining any other cognitive position, viewpoint or perspective asides our own "eyes" truly takes an effort that might be deemed impossible. Regardless of how many leaps and skips one tends to perform cognitively, ultimately there are always "the spectacles" of self, which recurrently absorb the content of cognition. Egoism as such cannot be exempted. This position can be found under the term "reality-tunnel", coined by Timothy Leary, and further expanded on extensively by Robert Anton Wilson. ${ }^{17}$

"Each of us is trapped in the reality-tunnel (assumption-consumption) his or her brain has manufactured. We do not 'see' it or 'sense' it as a model our brain has created. We automatically, unconsciously, mechanically 'see' and 'sense' it out there, apart from us, and we consider it 'objective'."'18

This "reality-tunnel" can be ruminated only on a conceptual level, reflexively, while being immediate cognitive contact with the objects of thought, and as such a prerequisite for "what-and-how" of knowledge. Much of the experience and understanding of the world depends on this "reality-tunnel" receptacle and its configuration. It might be added that this "reality-tunnel" is actively evolving with the inclusion of more additional elements that it systematises as a valid image of reality. Fundamentally, the ego is the necessary capacity and condition for this configuration. Also, as it is explained further in the following chapter, once the ego attains certain qualities, or modes of explication as its defining features, that particular self, observed as a position (i.e. egoism) with its "reality-tunnel" is altered, and these standards are measuring all further interaction with the world (cognitive, sensory, practical), as a framework. However, this set of modes of explication of ego is not the same 
as the ego on the fundamental level of self for each individual. On this note, it is also important to emphasise that in the psychiatric evaluation, there is also the collision of two "reality-tunnels", and evaluator measures the opposing one to his own. This is also the case with dialogues in general. This "realitytunnel", being of a complex built, is becoming enlightened and discovered for both participants of the dialogue. This collision of two (or more) differentiated "reality-tunnels" of complexities may also come to misunderstanding and misjudgments, and usually these occur in a primitive state, as being outlined by Wilson.

\begin{abstract}
"When we meet somebody whose separate tunnel-reality is obviously far different from ours, we are a bit frightened and always disoriented. We tend to think they are mad, or that they are crooks trying to con us in some way, or that they are hoaxters playing a joke. Yet it is neurologically obvious that no two brains have the same genetically-programmed hard wiring, the same imprints, the same conditioning, the same learning experiences. We are all living separate realities. That is why communication fails so often and misunderstandings and resentments are so common. I say 'meow' and you say 'Bow-wow', and each of us is convinced the other is a bit dumb." 19
\end{abstract}

On the egoism - narcissism line, focusing on the NPD feature of overestimation of the importance of self, which consequently in the necessary interaction with the world implies underestimation of the importance of all other and everything else besides self, and not only implies but depends on the possibility of this distinction between I - all-otherness, this conceptual demarcation between egoism and narcissism can be illustrated on a specific example. Most often, the society is prone to declare a person as narcissistic on the moral basis when a particular individual is putting oneself in front of other members of society, often endangering, or oppressing others of equal opportunities. In simple words, NPD manifests as deeply rooted selfishness, thanks to the significant amount of complexes, which form "reality-tunnel" that corroborates this particular set of moral standards as desirable. However, this selfishness of narcissism has a completely different meaning than the alleged selfishness of pure egocentrism. Because, as it has been stated above, egocentrism is an unavoidable perspective, as a cognitive bias, belonging to and present in each

15

Diagnostic and Statistical Manual of Mental Disorders, American Psychiatric Association, Washington (DC) 1994, p. 658

16

Susan Krauss Whitbourne, "It's a Fine Line Between Narcissism and Egocentrism", Psychology Today (7 April 2012). Available at: https://www.psychologytoday.com/intl/blog/ fulfillment-any-age/201204/it-s-fine-line-between-narcissism-and-egocentrism (accessed on 16 April 2020).

17

"16. Because of this, a common claim from both proponents and critics of distinct realities is that there is no such thing as an objective reality 'out there'. This argument can be long-winded and unproductive, as it is, so far, impossible to prove or disprove either way. Those who investigate the nature of 'true reality', such as quantum physicists or
Buddhist monks, describe it as being so weird and incomprehensible that we may never understand what 'true reality' is, assuming of course that it exists in the first place. 17. This is one of Tim's ideas that has been expressed much better by the writer Robert Anton Wilson than by Leary himself. Indeed, Wilson is often credited with creating the phrase 'reality tunnels', but when asked about it he is quick to give Leary the credit." - John Higgs, I Have America Surrounded. The Life of Timothy Leary, Barricade Books Inc., Fort Lee (NJ) 2006, p. 282.

18

Robert Anton Wilson, Prometheus Rising, New Falcon Publications, Tempe (AZ) 2000, p. 210 .

19

R. A. Wilson, Prometheus Rising, pp. 210211. 
individual, and as such, it is not arbitrary. While narcissism, meaning selfishness, is only one of a numerous possible explications of ego and as such, it can be altered - therefore it is consciously or unconsciously chosen moral quality. Ultimately, to be selfish or charitable does not reflect on being egoistic or non-egoistic. Ego is a universal and necessary condition for every human being in action. By that, the ego is the last instance that has the jurisdiction to legitimise any possible position and to direct the practical action following the supported views. Behind every conscious action, there is an egoistic consciousness and only secondary, in particular cases, these manifestations differ as different modes of action. By this, it should be emphasised that every conscious action is stimulated by the ego, with the expected trajectory which is supposed to lead back to self; no matter of the explication of that action. Max Stirner offers a straightforward explanation on the given subject:

"But now those people go on and ask: For whose sake do you care about God's and the other commandments? You surely do not suppose that this is done merely out of complaisance towards God? No, you are doing it - for your sake again. - Here too, therefore, you are the main thing, and each must say to himself, $I$ am everything to myself and I do everything on $m y$ account. If it ever became clear to you that God, the commandments, etc., only harm you, that they reduce and ruin you, to a certainty you would throw them from you just as the Christians once condemned Apollo and Minerva or heathen morality. They did indeed put in the place of these Christ and afterward Mary, as well as a Christian morality; but they did this for the sake of their souls' welfare too, therefore out of egoism or ownness." ${ }^{20}$

Just as there are various societies with different and even mutually conflicting value systems, there are variously developed egos, also regarding attained value systems, and these may be in opposing relations. Nevertheless, as comparative anthropology shows, these different establishments do not imply that some are not societies. The same is true for individuals that have attained different value systems, built-up on their egos - ego is a universal category. What these differences indicate are merely differently configured "reality-tunnels", a problem closely related to the concept of moral relativism. Stirner's explanation quoted above contains a brief formal outline of a paradigm shift in one of many historical contexts. A more extensive comparison between different societies and their customs in the context of cultural diversity and moral relativism can, for instance, be found in Marquise de Sade's Philosophy in the Bedroom, mainly on the topic of 'Manners' in the pamphlet, ${ }^{21}$ of which Timo Airaksinen stated:

"According to the second interpretation, all cultures support different and mutually conflicting values. This relativism can be shown by means of comparative anthropology; to support it, Sade himself uses empirical data in a bewildering manner." 22

In both cases, there is a sort of legislator that is authorised to approve and/ or disapprove certain set of values. The only difference is that on the level of society this duty may be put in the hands of multitude, while on the level of the individual, this duty is carried out by ego. That does not say that ego in its realisation is unambiguous, but more on this in the following chapter. Wilson also draws a correspondent conclusion based on his anthropological analysis of the more recent social convictions.

"None of the reality-models discussed (...) however bizarre they may seem to some readers, are any more arbitrary than the official reality-model known as consensus-reality, which is a statistical average and not nearly consensual as it seems. Travel 100 miles in any direction, and the consensus begins to crumble. Travel 1000 miles and very little consensus is left (...). ${ }^{23}$ 
Therefore, it is no surprise that Stirner explains this aspect of ego in the context of theology, given that theological convictions are the principles for further development of the image of the world. However, the ego is even above (or preceding to) god; as also clearly stated on another point in his work in which this hierarchy is well explained:

"Before the sacred, people lose all sense of power and all confidence; they occupy a powerless and humble attitude toward it. And yet no thing is sacred of itself, but by my declaring it sacred, by my declaration, my judgement, my bending the knee; in short - by my conscience."24

Furthermore, on this ethical point from the egoist perspective, it is worth noting that ethics withheld in Stirner's philosophy is the affirmative ethics of living. It opens the understanding of an individual for the realisation that it is an active participant of the world, meaning that the actions taken by the individual are important in the overall figuration of the world. Recurrently, this open perspective on egoism as a universal human state and position equalises self with the world, the world being the receiving content of individual's cognition, with an ultimate conclusion in the hypothesis "if I want good for myself, then I want good for the world".

Naturally, much of this depends on the "reality-tunnel" configuration and the ability to assess the range of beings, in order not to transgress into the ethos of another being and subject it to self-interest - which is the narcissistic failure of stating "I know what's good for you". Of course, this egocentric cognitive bias requires ethical understanding for valid selection bias and confirmation bias in the ultimate action. These three actions are all taking place in ego with the effects of chosen actions occurring in the world. Stating that one is non-egoistic, or anti-egoistic is a hypocritical statement based on misunderstanding and presumption that one can be someone or something else aside itself. Looking at this complexity of intersubjective relations, and the erroneous misunderstanding of egoism as narcissism, it also leads to a conclusion in equation I = world. Because, the complex configuration of ego is also configured from the interactions that are occurring within the world, and as such, a certain " $\mathrm{I}$ " is an explication of the universal flow of beingness. This concerns the ethical understanding of the relation between free will and predestination or destiny. The self, which is omniscient, omnipotent and exalted in eternity has determined the course of its orbit, simultaneously determining all that befalls it and that it interprets as destiny. In truth, it is the necessary effect of the will. That is why it befits to state that the world also is ego, and this multitude of relations in the endless domain of intersubjectivity co-produces different egos. That is why each consciousness has the impression that it is in the centre of the universe, but different complexes may cloud understanding and judgment, and this can then lead into narcissism, as cognitive malformation. Thus,

20

Max Stirner, The Ego and His Own, Benjamin R. Tucker, New York 1907, p. 129.

21

Cf. Marquis de Sade, "Yet another effort, Frenchmen, if you would become republicans", in: Marquis de Sade, Philosophy in the Bedroom, translated by Richard Seaver, Austryn Wainhouse, Grove Press, New York 1971 (Digitized by Supervert 32C Inc., 2002), pp. 91-129.
22

Timo Airaksinen, The Philosophy of Marquis de Sade, Routledge, London - New York 1995, p. 12.

23

R. A. Wilson, Prometheus Rising, p. 237.

24

Thus, by ego. - M. Stirner, The Ego and His Own, p. 63. 
it is impossible to be narcissistic and not egocentric, or non-narcissistic and not egocentric, but it is possible to be narcissistic and egocentric, or non-narcissistic and egocentric. In all these relations, ego as consciousness remains to be the ultimate instance of an individual, acquiring a particular set of characteristics from the multitude of relations that are present in the world. The logic behind the configuration of these characteristics is another step deeper in the ego complexities.

\section{The Constitution of the Ego}

"We are what we think. All that we are arises with our thoughts. With our thoughts we make the world." 25

The highlighted thought, rightly or not ascribed to Buddha, ${ }^{26}$ here serves as a guideline in outlining the structure of what is within this research understood under the notions of the ego complexities, ego and subjectivity that bears the same. As previously noted, the ego is a universal subjectivity which can be found and recognised in every unit of a human being. ${ }^{27}$ Ego is a general basis, founded on thought and constituted of thought, and it represents the same principle of all particular human minds, as a cognitive apparatus. This cognitive principle - ego - is the very thing that conditions experience of the world understood as cosmos and it shapes the very image of this world, provides the foundation for the build of judgments about the world and for the instructions how to act within that world and with that world. To understand how ego functions, Wilson uses a simplified comparison with the work of computer. Important note regarding this comparison is that one should always keep in mind that it is only a simplified model to clarify the disarray and intricacy of ego, while the model itself is not a disarray in question - just as a map of a territory is never the territory that is mapped. ${ }^{28}$ Every computer has two general aspects: hardware and software. Hardware is localised and represents concrete, tangible components in a clearly defined form. Software is constituted out of programs that may exist in the multitude of various forms and even in complete abstraction as well. ${ }^{29}$

\footnotetext{
"A program can be 'in' the computer in the sense that it is recorded in the CPU or on a disk which is hitched up to the computer. A program can also exist on a piece of paper, if I invented it myself, or in a manual, if it is a standard program; in these cases, it is not 'in' the computer but can be put 'in' at any time. But a program can be even more tenuous than that; it can exist only in my head, if I have never written it down, or if I have used it once and erased it." ${ }^{30}$
}

This would conditionally state that hardware is more real than the software because it is localisable in the space-time. However, software has a greater share in reality in the sense of independence of hardware, given the possibility to rematerialise or re-manifest itself in another computer, if the prior has been destroyed. ${ }^{31}$ The idea behind this analogy is to demonstrate that this complementarity of the relationship between hardware and software exists in the ego as well, to a certain extent. Concerning ego, hardware would represent ego in the sense of general capacity for further explications and adoption of different modes of programs of thinking - and therefore the subject, biological condition, or medically speaking - brain, or philosophically - psyche. Software, or the programs of the hardware (or for the hardware), is any possible explication of ego, and therefore the objective part, as that which is not solely reducible to a subject and that which has its sociological dimension. In different terms, this refers to that property of each being due to which it has its 
genetically and historically acquired features. While genetic cause subsumes all that is implanted in the constitution of the being before its emergence in the present form, historical causes are all those influences that acted upon the being thus participating in its shape and development, sometimes even stimulating certain genetic predisposition to develop. This virtual division, needed only for the analytical view of the ego, can be understood as a division to internal and external components of the ego. Since the human being is in this respect two-componential - individual and social - "all human psychology, it is contended, must be the psychology of associated man, since man as a solitary animal is unknown to us, and every individual must present the characteristic reactions of the social animal if such exist". ${ }^{22}$ This historical development, or social component, or external influence on the configuration of an individual ego is apparent in what is held to be scientific-moral standard of the age, as shown by Jones.

"Further, when the general attitude towards a question changes in the course of time, this is often due at least as much to modification of the prevailing affective influences as to the accumulation of external evidence; for instance, the average man of to-day does not hesitate to reject the same evidence of witchcraft that was so convincing to the man of three centuries ago, though he usually knows no more about the true explanation of it than the latter did." ${ }^{33}$

These mental representations of reality that individuals hold, and held throughout history in a vast diversity of ways, constitute a great part of what is perceived as ipseity, and recurrently of the conditional reflexes that are responsible for emotional and psychic stability. How ego as subjective-objective assembly executes its operations can be explained with the notion of aesthetic preference, ${ }^{34}$ in which input variables are: pleasure and pain, or that

25

Buddha, The Dhammapada, translated by Thomas Byrom. Available at: http://www. insightflorida.org/uploads/dhammapada.pdf (accessed on 16 April 2020).

26

There are other researchers and translators of Buddhist thought that consider this Byrom's translation dubious and incorrect. However, for the research conducted here, this is only of a secondary matter, and even the alternative translations are in adequacy with the main argument. "There's nothing in the Pali original that mentions 'thoughts' or 'the world' at all, never mind that we are what we think, or that our thoughts create the world. This particular translation is from a well-loved version of Dhammapada, by Thomas Byrom. According to his US publisher, Shambhala (...) there's no mention of his having taught or studied Pali, which may explain the poetic, but very non-literal nature of his Dhammapada. It may also explain why publisher calls Byrom's version a 'rendering' rather than a translation." - Bodhipaksa, "We are what we think", Tricycle. The Buddhist Review (fall 2014). Available at: https://tricycle.org/magazine/we-are-what-we-think/ (accessed on 16 April 2020).
27

For the requirements of this research, the subject is narrowed only to human psyche.

28

Cf. R. A. Wilson, Prometheus Rising, pp. 33-43.

29

Cf. ibid

30

Ibid., p. 37.

31

Cf. ibid., pp. 33-43.

32

Wilfred Trotter, "Herd instinct and its bearing on the psychology of civilized man", in: Wilfred Trotter, Instincts of the Herd in Peace and War, The Macmillan Company, New York 1917, pp. 11-41, p. 12.

33

Ernest Jones, "The Psychopathology of Everyday Life", The American Journal of Psychology 22 (1911) 4, pp. 477-527, p. 524, doi: https://doi.org/10.2307/1412796.

34

Every action, judgement, understanding and standpoint is recurrently egoistic, based on 
which the subject itself evaluates as useful or harmful to itself, and after the cognitive process of these variables, as output occurs a reaction, either approach or flee. ${ }^{35}$ Regarding the cognitive process of the mentioned variables a cognitive dyad may be introduced, referring to the mechanism constituted of two parts, with a description, which Wilson adopted by Leonard Orr, as thinker and prover.

"The Thinker can think about virtually anything. History shows that it can think the earth is suspended on the backs of infinite turtles or that the Earth is hollow, or that the Earth is floating in space; comparative religion and philosophy show the Thinker can regard itself as mortal, as immortal, as both mortal and immortal (the reincarnation model) or even as non-existent (Buddhism). It can think itself into living in a Christian universe, a Marxist universe, a scientific-relativistic universe, or a Nazi universe - among many possibilities (...). The Prover is a much simpler mechanism. It operates on one law only: Whatever the Thinker thinks, the Prover proves. (...). If the Thinker thinks that the sun moves around the earth, the Prover will oblingly organise all perceptions to fit that thought; if the Thinker changes its mind and decides the earth moves around the sun, the Prover will reorganise the evidence." ${ }^{36}$

When it comes to the interaction between these two supposed counterparts of the ordinarily unified cognitive apparatus, described actions are not referred to the outside reality, if objective reality is to be supposed. These processes (thinker-prover) and their interplay are concerning only the mental representation and order of the images that co-constitute one's overall ego complexity. For this clarification, it is advisable to consider some of the mentioned examples and the concepts spanning from those, which can be evaluated as absurd to those convictions, which might be upheld as plausible. On the subject of the encounter of subjective-objective factors in self, further projected as a valid representation of reality, Peter Berger and Thomas Luckmann developed a theory, predominantly covering the "software" objective part of this relation in the book The Social Construction of Reality, concluding that:

"In the dialectic between nature and the socially constructed world the human organism itself is transformed. In this same dialectic man produces reality and thereby produces himself." ${ }^{37}$

Each individual ego bears a different complexity in respect to its subjective configuration, rooted in its genealogy, and to the objective additionally implemented programs that are in its surrounding environment. Also, each particular complexity of ego will depend on when-and-how the encounter with a specific social construct ensued, making it all more difficult to predict or even affirm a specific personality and its disorders. Naturally, this logic follows the chronological development of a person to a certain extent, and some thoughts that are deeply rooted will remain fundamental to the older age - these are the imprinted thoughts.

"At puberty, another DNA trigger fires and RNA messengers initiate another morphological mutation of body-mind. The 'adult personality' is imprinted and conditioned." ${ }^{\prime 3}$

However, this morphological mutation mostly "robs" an individual of different possibilities that were realisable up to the point of commencement of that particular mutation.

"It is the function of the nervous system to focus, to select, to narrow down; to choose, from an infinity of possibilities, the biochemical imprints which determine the tactics and strategies that ensure survival in one place, status in one tribe. The infant is genetically prepared to learn any language, master any skill, play any sex role; in a very short time, however, he or she becomes mechanically, robotically, fixated to accept, follow and mimic the limited offerings of his social and cultural environment. In this process, each of us pays a heavy price." ${ }^{39}$ 
This makes it all more difficult in further development to alter the complexities once inhabited within the specific ego, and this may cause problems in social interaction and development of an individual within a society that requires different configuration from the one established.

"We, as a species, exist in a world in which exists a myriad of data points. Upon these matrices of points, we superimpose a structure and the world makes sense to us. The pattern of the structure originates within our biological and sociological properties." ${ }^{40}$

Within the scope and reach of human psyche, the primary carrier of a certain complexity of various data points is the individual, but the carrier may also be a certain group of people or society, which has taken hold of that specific set of data points and enliven it through its actions. Superimposition of a structure is recurrently the accommodation of the incoming data points from the outer world according to the established "reality-tunnel" which is in the effect of that body (being an individual or society), due to biological ("hardware") or sociological ("software") properties.

The unit that upholds a certain set of properties is not limited to one individual, but it can adequately also be a society. Society guarantees that the "software" will survive and that the program of thought that includes a whole bundle of values is enabled for attainment in upcoming individuals. However, not only that problems in the collision of incompatible "reality-tunnels" happen on the inter-social level, but these often emerge on a level society-individual. In the latter case, if an individual ego complexity fails to meet the criteria of a dominant "reality-tunnel" of society, then it becomes diagnosis and the subject of medical evaluation, with the aim to become reprogrammed (even though that is not always possible, under condition that branches of personal development were locked in the process of morphological mutation). To get the individual to be a fully functioning member of society, it has to become brainwashed. ${ }^{41}$

"The easiest way to get brainwashed is to be born. All of the (...) principles then immediately go into action, a process which social psychologists euphemistically call socialisation." ${ }^{42}$

The problem of socialisation is more reflected upon when it comes to the deciding an adequate approach in rearing, upbringing and educating children,

ego. The differences concerning particular development of ego and its leaning to one set of values over the other are the matter of aesthetic preference of that particular ego and are surface layer of the ego.

35

Cf. R. A. Wilson, Prometheus Rising, pp. 33-43.

36

Ibid., pp. 25-26.

37

Peter Ludwig Berger, Thomas Luckmann, The Social Construction of Reality. A Treatise in the Sociology of Knowledge, Penguin Books, London 1966, p. 204.

38

R. A. Wilson, Prometheus Rising, p. 140.

39

Ibid., p. 124.
40

Michael A. Persinger, Gyslaine F. Lafrenière, Space-Time Transients and Unusual Events, Nelson-Hall, Chicago 1977, p. 3.

41

"From the viewpoint of neuro-sociology, how I perceive 'myself' and 'my world' depends on how each circuit has been wired in my brain. Society has always known how to wire children; the process is called acculturalization; it explains why children of Catholics tend to become Catholics, children of Samoans fit into Samoan society, children of Communists become good little Communists, etc. Each generation 'brainwashes' the next." - R. A. Wilson, Prometheus Rising, p. 155.

42

Ibid., p. 169. 
defended by the advocates of the importance of creativity, critical thinking and personalisation in the overall approach to a human being. The approach that imposes sole template on a group of various individuals is in that respect one-way communication and from the perspective of interpersonality and intersubjectivity - a communication failure and erroneous rearing, disgraceful towards the dignity of an individual.

"Lack of understanding of (...) morphological changes, and their persistence in imprint circuits in the brain, is responsible for most failures in communication, and for the general sense of exasperation with which we too often confront each other. Since everybody's imprints are a little bit different - the average is that which nobody totally is - we all feel at times like the legendary Quaker who told his wife, 'All the world is mad but me and thee, and sometimes I wonder about thee.' Reichians, disciples of Dr. Spock and the Summerhill School, etc. have called attention, with some impatience, to the brutality and stupidity of many of our traditional child-rearing methods. These methods are 'brutal' and 'stupid' only if, like the above mentioned heretics, one regards the goal of child-rearing as the production of a sane, balanced, creative [NOT CREATED] human being. THIS HAS NEVER BEEN THE GOAL OF ANY SOCIETY IN THE REAL WORLD. The traditional methods are quite logical, pragmatic and sound in fulfilling the real purpose of society, which is not to create an ideal person, but to create [CRATE] a semi-robot who mimics the society as closely as possible - both in its rational and its irrational aspects, both as the repository of the wisdom of the past and as the sum total of all cruelties and stupidities of the past." ${ }^{43}$

The form changes from childhood to adulthood, since the prior allows the moulding through upbringing, while the latter then requires psychiatric treatment as alteration of the psyche and its stiffened complexities. In the cases in which institutions fail to create a "normal" unit, they are obliged to "normalise" the existent one, even though

“... from a psychological point of view perfect mental normality does not exist. In other words, everyone shows numerous defects in mental functioning that are manifestations of dissociated, repressed, psychic material (...)." ${ }^{44}$

What is understood as a disease is, again, rooted in one specifically configured "reality-tunnel" (or one part of it), as long as it regards arbitrary worldview.

“... the border-line between mental health and disease is much less sharp even than is generally supposed. The distinction between the two is really a social one, rather than a psychopathological one, just as the distinction between sanity and insanity is primarily a legal one." 45

The problem with the society taken as a criterion of self-development is in its rigidly and baldly constructed "reality-tunnel" which lacks inclusivity and flexibility, relying mostly on one of two modes. Either it relies on statistical average, thus setting as a standard something that is supposedly presented everywhere, while in reality is present nowhere; or it relies on one set of values and legitimised thoughts that are to be acquired by all members, regardless of its origin in one particular "reality-tunnel". This second reliance of social standard for individual development suffers NPD stretched to the level of society, falling under the influence of one particular complex which is given the absolute primacy over all other possible explications. The subjective power and relation of thinker and prover are easily perceived in other humans, but it is not so easily recognisable in one's egoism. Therefore in a broader scope, on a society level, due to certain norms, particular idealisms often emerge, blind for the very mechanisms of their genesis in a prover-thinker interplay.

"A further reason is that some one under the sway of strongly affective influences thinks not only that any one differing from him must be deficient in reasoning power, but also that the 
views of the latter are themselves stupid. In attempting to controvert these, therefore, he, unconsciously distorts them until they really are foolish, and he then find it easy to demolish them." ${ }^{\prime 4}$

This complexity of thinker and prover can also be named as the problem of coherentism, becoming indicative when the system tends to survive no matter the cost, even if it means manipulating with the proofs, to maintain its systematics. This results in a proclamation of "more objective" ways of thinking, which generally is one pseudo-concept.

"The history of mankind is also the history of one Utopia after another, being enunciated with enthusiasm and vigor, calling upon all the facts of faith and science (as they existed at that moment in space-time) to corroborate the fantasy. A decade or maybe a century elapse - and the fantasy is no more. The Utopia has gone down the drain to join all the other Utopias of earlier primates." ${ }^{47}$

Such disorientation in ideologies is what is being called fanaticism, and it is connected with a certain unawareness of ego as a delegator of every position, which results in an individual who lost their creative character and became the pupil of their fantasy, absorbed in the object without the reflection of their self. The deeper the roots of such one idea extends, the more obscure the complex becomes, and the more pious attitude is taken in dealing with one such idea. It becomes an expression of narcissism on the level of the individual psyche, of one complexity rising in importance above all other aspects of the ego, and eventually the ego itself. This struggle for dominance of one fragment of ego over the whole aggregate of ego complexities leads into psychic mares and sufferings, splitting the psyche and subordinating it to a certain fantasy, virtually torn from its very root, exalted and exaggerated in importance.

"Infantility, compulsive behaviour, adherence to adolescent expression both of feeling and thinking - these are the traits which interfere with the free growth and expression of the psyche. Not only so, but if persisted in, and if they become chronic or severe or intense, we have the production of psychosis, true schizophrenia, and other forms of insanity - rusts which eat up the metal of consciousness and involuntarily disintegrate the ego itself." ${ }^{48}$

For the sake of infatuation of one such idea with a practical purpose of subjection, ego unconsciously performs virtual separation of the very ideal and self only as a pragmatic vehicle. In this way, the piety of such construct seems more legitimate - its origin is fictively not humane, but divine. This process legitimises the discourse of divine providence, promulgation without coping the fact of self as the creator of this fixation, but providing the foundations for proclaiming oneself an oracle and eventually the leader of society on a divine mission. Reflections on the duality that occurs in aspiring transcendence, cleaving the ego in the process, are also traceable in the works of Austin Osman Spare, focusing on unawareness of self in every such process.

43

Ibid., p. 140.

44

E. Jones, "The Psychopathology of Everyday

Life", p. 521.

45

Ibid.

46

Ibid., p. 525.
47

Israel Regardie, "Introduction", in: R. A. Wilson, Prometheus Rising, pp. 17-21, pp. 18-19.

48

Israel Regardie, The Philosopher's Stone, Llewellyn Publications, Woodbury (MN) 1970, p. 21. 
"The foundation of religion and faith is the human outreach toward transcendence, as those who are aware of their impermanence strive to embrace, and be embraced by, that which lies beyond the coils of time and death. Spare observes that however the Absolute may be conceived, the very act of objectifying it as other than what one is creates a fundamental dualism which cannot then be resolved; therefore all doctrines are doomed to failure from their inception, and as long as transcendence is imaged as a god or believed in as a power, it remains unattainable. Self gazes upon self through the mirror of its own making. This is the Law of Duality - the nature of belief, and the very substance of Ego." ${ }^{49}$

Seemingly, the deeper the gap becomes between knowing self as the creator of the supposed transcendence and the transcendence itself, followed by the oblivion of self as a creator of this disposition, the stronger the reliance and belief in such construct becomes.

"Spare's antidote to this bondage of religion is to disengage the mutual tension between 'believer' and 'believed-in' by simply removing that which at once unites and separates them - the believing. He asserts that belief is not an end in itself, but is a tangible end-product of the process which moves outwards into the world of created forms, shaping personality, conditions and events; it can be traced backwards from its object to its origin (...). ${ }^{{ }^{50}}$

What this relation of such belief reveals of its origin, i.e. ego, is that ego, for the sake of intrusiveness of oneself, prefers choosing itself as being separated from the whole, only to become a medium of the holy ukase; to understanding the unity in whole as the divine and itself as a part of that divinity. The completion of one such narrative also requires a certain antagonism, which is formatted in the proclamation of the foul origin of the world apart from the supposed transcendence, referring to the fall from perfection into a tragic situation and tragic struggle for survival, oblivious to unity, instead being unit-oriented. It is an error in recognition, same as with the narcissism, which is also characterised by lack of knowledge or awareness of that objectivist part of ego, which gains its form out of the interaction with the surroundings, which is the very ground for the development of the idea of self. Once this deficiency occurs, one can only place oneself in the initial place of cause.

The suggested trajectory that is supposed to keep the psyche away from falling into undesirable states is a cognitive method that views upon reasoning as a mechanism of becoming aware through enlightening the position of self in relation to others and perceives constitution of the self, inseparable of the historical-genetic loop. From another aspect, infatuation with the particular ideas with a tendency to arrange the reality according to these ideas is a tragic error of attributing exaggerated meaning of one fragment or one part of the complex formation that is ego. Historical flow has shown that development and extension in space-time happen despite imposed completions in accordance to one particular image of reality, rather than for it. The prerequisite for the progress is the introduction of the new elements into the system and inclusiveness, which usually requires reworking the current program framework. The opposite direction is the one of biological reductionism, founded on fear from everything that transgresses the existing framework. Rational capability and duty are to systematise these ego complexities and disallow them to lead into destabilisation and passivity, holding the reason greater than fate.

\section{Concluding Artistic Reflection on the Subject}

Among possible interdisciplinary approaches to the given subject, there might be different means for achieving the desirable resonance in understanding 
ego, self, subject-object relation and the complexities here inscribed. One such method is the artistic expression and its candour to various interpretations which aim to stimulate reflection upon presupposed. One such attempt of explaining the mental representation and experience of reality is connected with well-known Italian Renaissance artist Michelangelo Buonarroti and one of the scenes from the frescoes covering the ceiling of the Vatican's Sistine Chapel, mostly known as - Creation of Adam (Image 1).

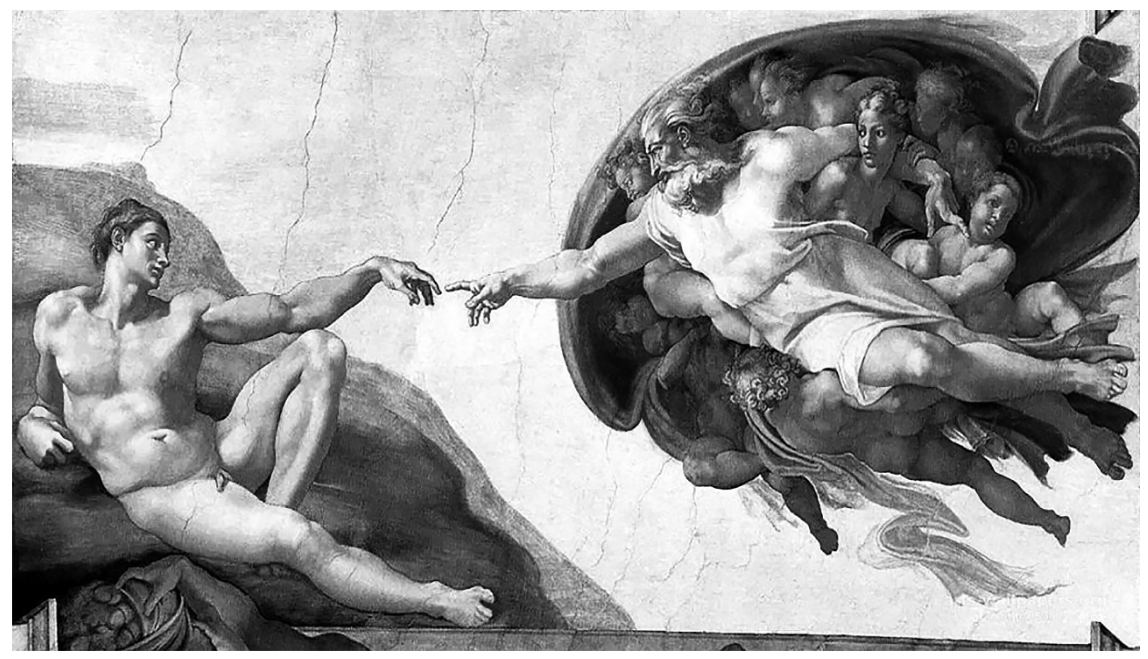

Image 1: Michelangelo Buonarroti, Creation of Adam

However, there are certain suspicions regarding the Michelangelo's work, considering details from his biography, which throw a different light on the meaning of mentioned fresco, such as the one brought out in the year 1990 by the author Frank Lynn Meshberger in his article "An Interpretation of Michelangelo's Creation of Adam Based on Neuroanatomy". In the article, the author suggests that the more appropriate title of the fresco would be the Endowment of Adam, based on the belief that there is a special message encoded within the image. ${ }^{51}$ The main idea of the article is explained as follows:

"The Creation of Adam fresco shows Adam and God reaching toward one another, arms outstretched, fingers almost touching. One can imagine the spark of life jumping from God to Adam across the synapse between their fingertips. However, Adam is already alive, his eyes are open, and he is completely formed; but it is the intent of the picture that Adam is to 'receive' something from God. I believe there is a third 'main character' in the fresco that has not previously been recognised." 52

The "third main character" the author is mentioning is the intellect, which is, given that the medium is visual art, symbolically represented in the shape of a brain. Meshberger affirms his interpretation with a comparative studies of Michelangelo's frescoes, his sonnets that contain praises to the intellect as the

49

Gavin W. Semple, Zos-Kia. An Introductory Essay on the Art and Sorcery of Austin Osman Spare, BCM Fulgur, London 1995, p. 20.

50

Ibid.

51

Cf. Frank L. Meshberger, “An Interpretation of Michelangelo's Creation of Adam Based on Neuroanatomy", JAMA 264 (1990) 14, pp. 1837-1841, doi: https://doi.org/10.1001/ jama.264.14.1837.

52

Ibid., p. 1837. 
“divine part", with artists' biography documented by his contemporary, Giorgio Vasari, which testifies that Michelangelo was an avid student of human anatomy and had been performing dissection of bodies. ${ }^{53}$ Ultimately, the author demonstrates the supposed neuroanatomical sketch, which was precisely painted-in the fresco (Image 2). ${ }^{54}$

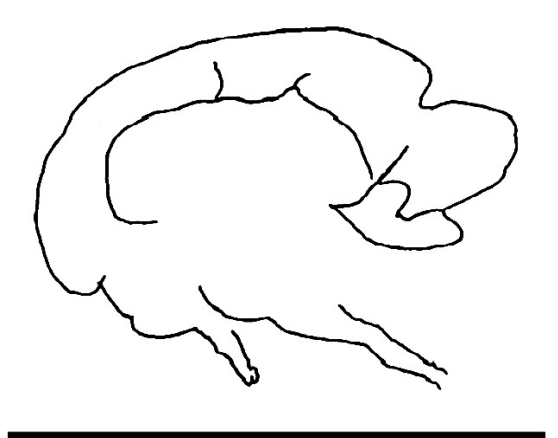

Figure 4

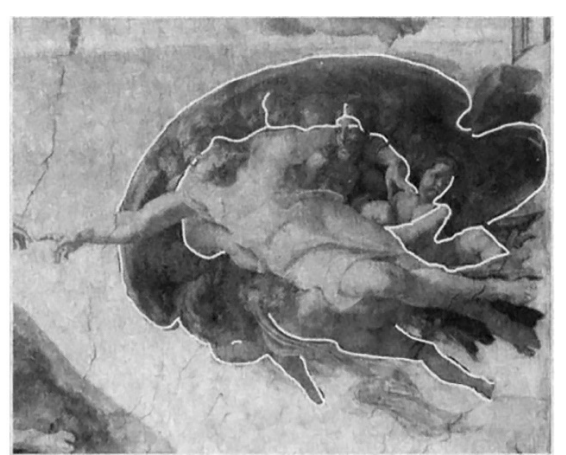

Figure 13

Image 2: neuroanatomical sketch (Figure 4) applied to the fresco

(Figure 13). From: F. L. Meshberger, "An Interpretation of Michelangelo's Creation of Adam Based on Neuroanatomy".

As demonstrated, the shell around the god and the angels in the fresco resembles cranial shape. Meshberger argues that there are enough parts symbolically, yet with peculiar precision, included ${ }^{55}$ that it can validly be stated that the image is a neuroanatomical sketch. As the author suggests, this examination can be performed even to more minute details. However, once the key shapes are recognised and Adam's prior vibrancy determined, it is appropriate to state "that what God is giving to Adam is the intellect". ${ }^{56}$ However, still consulting the Meshberger's comparative analysis, and his conclusion that "God is compatible with the brain" ${ }^{57}$ a somewhat different conclusion might also be suggested, having in mind another aspect.

"Those students then who would be better instructed must first know there is an universal agent, Who when He was disposed to create had no other pattern or exemplar whereby to frame and mould his creatures but Himself. But having infinite inward ideas or conceptions in Himself, as He conceived so He created: that is to say, He created an outward form answerable to the inward conception or figure of His mind." 58

This approach or reversal in approach answers why the image of a god is in the mind of human being anthropomorphic, claiming that it is also anthropogenic. Having the impression of the world based on an intellectual conceptualisation of the world, and holding the intellect as the supreme faculty of the self, it easily undergoes the process of deification. The whole divine aspect of the intellect is even more comprehensible if the god is understood as demiurge and not as an absolute creator - the one that ordains and adjusts material, but does not create it. The interpretation from this point of view would state that Adam thought of god, but possibly, in attempt to position the demiurge over demiurge, lost the perspective of self, as a being with the capacity and ability "to "plan the best and highest' and to "try all things received" ,59 as Meshberger's analysis suggests man as a being is. 


\title{
Bernard Špoljarić
}

\section{Kompleksnosti ega}

\begin{abstract}
Sažetak
Istraživanje kompleksnosti ega polazi od jastva kao složenog koncepta, pretpostavljenog pridolazećim dijagnostičkim konstruktima, kojima se svako pojedino jastvo želi medicinskikvalitativno evaluirati. Uz objašnjenje pojma, cilj je ukazati na jasnu distinkciju između egoizma i narcizma, pri čemu je narcizam tek jedan od mogućih modaliteta eksplikacija jastva odnosno opće i univerzalne domene subjektivnosti. Kompleksnost ovdje u prvom redu ukazuje na samu po sebi nerazjašnjenu složenost ega te pripadajućih koncepata subjektivnosti i individualnosti. Prikaz općeg modela ega, njegovog sastava i operativnosti, pruža mogući zajednički temelj za terapeutsko, filozofijsko i moralno shvaćanje aporija vezanih uz psihopatologijska stanja prisutna kod naizgled emancipirane dovršene jedinke.
\end{abstract}

\section{Ključne riječi}

kognicija, kompleksnost, ego, egoizam, jastvo, narcizam, dokazivatelj, psiha, subjektivnost, mislitelj

\section{Bernard Špoljarić}

\section{Die Komplexitäten des Ego}

\section{Zusammenfassung}

Die Erforschung der Komplexität des Ego geht von der Ichheit als einem vielschichtigen Konzept aus, das angesichts der hinzutretenden diagnostischen Konstrukte vorausgesetzt wird, mit denen man jedwede einzelne Ichheit medizinisch-qualitativ zu evaluieren sucht. Neben der Erklärung des Begriffs ist man bestrebt, auf eine klare Distinktion zwischen Egoismus und Narzissmus hinzuweisen - mit Narzissmus als erst einer der möglichen Modalitäten der Explikation der Ichheit bzw. der allgemeinen und universellen Domäne der Subjektivität. Diesbezüglich verweist die Komplexität in erster Linie auf eine an sich unaufgeklärte Vielschichtigkeit des Ego sowie der dazugehörigen Konzepte der Subjektivität und Individualität. Die Darstellung des

53

Cf. ibid., pp. 1837-1841.

\section{4}

For full disclosure and gradual development of the comparison here made, it is highly advisable to read the full paper. For the conciseness of the argument, here are included only two steps, which are held to be representative enough.

\section{5}

"The sulcus cinguli extends along the hip of the angel in front of God, across God's shoulders, and down God's left arm, extending over Eve's forehead. The flowing green robe at the base represents the vertebral artery in its upward course as it twists and turns around the articular process and then makes contact with and proceeds along the inferior surface of the pons. The back of the angel extending laterally below God represents the pons, and the angel's hip and leg represent the spinal cord. The pituitary stalk and gland are depicted by the leg and foot of the angel that extends below the base of the picture. Note that the feet of both God and Adam have five toes; however, the angel's leg that represents the pituitary stalk and gland has a bifid foot. This same angel's right leg is flexed at the hip and knee; the thigh represents the optic nerve, the knee the transected optic chiasm, and the leg the optic tract." - Ibid., p. 1841.

56

Ibid.

57

Ibid.

58

I. Regardie, The Philosopher's Stone, p. 66. 59

F. L. Meshberger, "An Interpretation of Michelangelo's Creation of Adam Based on Neuroanatomy", p. 1841. 
allgemeinen Modells des Ego, seiner Zusammensetzung und Operativität, bietet eine etwaige gemeinsame Grundlage für eine therapeutische, philosophische und moralische Auffassung der Aporien, die zu den psychopathologischen Zuständen gebunden sind, die sich bei einem scheinbar emanzipierten vollendeten Individuum nachweisen lassen.

\title{
Schlüsselwörter
}

Kognition, Komplexität, Ego, Egoismus, Ichheit, Narzissmus, der Beweisende, Psyche, Subjektivität, der Denkende

\section{Bernard Špoljarić}

\section{Les complexités de l'ego}

\begin{abstract}
Résumé
Les recherches sur la complexité de l'ego prennent pour point de départ le concept du moi en tant que concept organisé, présupposé dans l'élaboration des diagnostics en émergence, par le biais desquels chaque moi individuel est évalué médicalement et qualitativement. En expliquant ce concept, le but est de mettre en évidence la distinction claire entre l'ego et le narcissisme, avec le narcissisme comme l'une des possibles modalités d'explicitation du moi, c'est-à-dire des domaines généraux et universels de la subjectivité. La complexité se réfère ici avant tout à l'organisation en elle-même inexpliquée de l'ego et des concepts associés de subjectivité et d'individualité. La présentation générale du modèle de l'ego, sa composition et son fonctionnement, offre une base commune pour une compréhension thérapeutique, philosophique et morale des apories liées aux états psychopathologiques présents chez, en apparence, des individus émancipés et accomplis.
\end{abstract}

\section{Mots-clés}

cognition, complexité, ego, égoïsme, moi, narcissisme, démonstrateur, psyché, subjectivité, penseur 